\begin{tabular}{|c|c|c|}
\hline $\begin{array}{c}\text { PORT SAID ENGINEERING RESEARCH JOURNAL } \\
\text { Faculty of Engineering - Port Said University } \\
\text { No. 1 parch 2021 } \\
\text { (Civil Engineering) }\end{array}$ & pp: $41-48$ \\
\hline
\end{tabular}

\title{
Durability Study of Metakaolin Concrete
}

\author{
S. Nour Eldin ${ }^{1}$, K. Sharobim ${ }^{2}$, H. M. Hassan ${ }^{3}$, and Sh. Ragheb ${ }^{4}$
}

Received 21 June 2020, Accepted 28 September 2020

\begin{abstract}
This paper aims to highlight the impact of using metakaolin on engineering properties of structural concrete. Metakaolin solved the pollution problem resulting from cement industry. Metakaolin produced by Calcining Kaolinite at high temperature to get pozzolanic material which can be used in concrete mixes. This paper aims to investigate and evaluate the durability of concrete containing metakaolin. The physical and chemical characteristics of metakaolin Concrete will be examined. Durability tests of metakaolin concrete involve chloride penetration, water permeability, abrasion, water absorption and concrete resistance tests. Behavior of metakaolin concrete under elevated temperature will be also studied. This paper demonstrates that replaced cement in concrete with metakaolin enhances durability and mechanical properties of concrete included different type of cement under various type of curing in the same time; Metakaolin concrete has a positive effect on compressive strength after exposure to escalated temperature.
\end{abstract}

Keywords: Metakaolin Concrete, Durability, Chloride Penetration, Elevated Temperature, pozzolanic material

\section{INTRODUCTION}

The widest spread cementitious materials that are used as concrete constituents are Fly Ash, GGBS and Silica Fume. They save energy, conserve resources and have many technical advantages "Sunny et al. [1]". Metakaolin, produced by controlled thermal treatment of kaolin, can be used as a concrete constituent, since it has pozzolanic properties "Sujjavanich et al. [2]". It is formed when mineral kaolin is heated to a temperature between 600 and $800{ }^{\circ} \mathrm{C}$ "Thankam -and Renganathan et al. [3]". The research works on metakaolin focuses on two main areas. The first is the impact of the kaolin structure on the conversion of kaolinite to metakaolinite and the use of thermo-analytical methods for the investigation of kaolin thermal therapy's "Sha and Pereira [4]".

\footnotetext{
${ }^{1}$ Civil Engineer at General Authority for Educational Buildings. Port-Said, Egypt, Corresponding Author, email: salyhosny@gmail.com

${ }^{2}$ Prof. of Civil Engineering Department, Faculty of Engineering, Suez Canal University, Ismailia, Egypt, email: k_sharobim@hotmail.com

${ }_{3}^{3}$ Prof. of Civil Engineering Department, Faculty of Engineering, Port-Said University, Port Said, Egypt, Email:hi_hgh@yahoo.com

${ }^{4}$ Civil Engineering Department, Faculty of Engineering, Port Said University, Port-Said, Egypt, email: shadyragheb@hotmail.com
}

DOI: $\underline{10.21608 / \text { pserj.2020.33448.1047 }}$
While the second one is concerned with the pozzolanic behaviour of metakaolinite and its influence on concrete properties "Taher et al. [5, 6]". Although there is a controversy in many partial topics, the knowledge level is satisfactory and continuously extended.

The concrete performance based mainly on the environmental conditions, the microstructure and the material properties of the concrete components. The two latter factors are strongly affected by the concrete components. It is apparent that the metakaolin presence affects the concrete performance.

The present work deals with the influence of metakaolin on concrete properties and more specifically the comparison of a produced metakaolin to a commercial one is probed.

In recent years, for the development of high- strength concrete, alternative cement materials have been used to improve performance with improved workability, strength and durability with reduced permeability, these substances are known as pozzolanic materials, including rice husk ash, fly ash, slag, silica fume and metakaolin. Pozzolanic reactions modify the microstructure of concrete and chemicals Pozzolanic reactions alter the concrete microstructure and chemistry of hydration products by consuming the release of calcium hydroxide $(\mathrm{CH})$ and by creating additional calcium silicate hydrate $(\mathrm{C}-\mathrm{S}-\mathrm{H})$, resulting 
in increased strength and reduced porosity, thus increasing durability. Metakaolin is a newly used Pozzolanic material in the concrete industry that increases strength, reduces sulphate attacks and improves the air-void network.

In the early 1960s, Metakaolin began to be used in concrete structures as an alternative to the part of cement used in the concrete mixture, and the interest in this substance has increased significantly in recent years due to its pozzolanic properties, which have had a positive effect on the resulting concrete where it causes the chemical stimulation of the active ingredients with calcium hydroxide (portlandite), that is considered to be a product of cement hydration "Sanjay et al. [7]".

\section{EXPERMENTAL PROGRAM}

\subsection{Material}

According to the principal of high strength concrete, the materials used in this experiment are shown in Table (1). There are two sorts of cement used in this research. The first one is the ordinary Portland cement manufactured by Sinai Company $(52.5 \mathrm{~N})$ was used in all mixes with a content $400 \mathrm{~kg} / \mathrm{m}^{3}$ as cement content. Testing was applied out based on the Egyptian standard specification [8]. The second type recommended for use in concrete attacked by sulphates is sulphate-resistant cement, which is primarily caused by the mixture of clinker and gypsum powder produced by Suez Cement Company and is compatible with the requirements of the standard specifications. The Egyptian standard specification [9, 10]. Kaolin is soft white clay and is widely used in the manufacture of paper and porcelain and is a natural mineral. Metakaolin is produced from kaolin, which is heat treated at $750{ }^{\circ} \mathrm{C}$. The used Metakaolin was produced by Nour-metec for building and Refractories Company. The aggregate used is brought from Suez Area, and its properties satisfy the Egyptian specifications. Sand was used to hone the grading curve of the granular mixture between coarse and fine aggregate. Table (2) shows the grading of fine and coarse aggregate used in all mixes. Pure bug-free fresh tap water that can be drank is used for mixing and curing research samples, according to the Egyptian Code of Practice (ECP 203/2018.) The term superplasticizers are referred to as high-range waterreducing (HRWR) admixtures which, without adding water, increase the workability of concrete. Sika Egypt Construction Chemicals is the third generation of super-plasticizers suitable for concrete and mortar. Sika Viscocrete 3425 Super-plasticizer is a polycarboxylate based super-plasticizer. The superplasticizer meets the requirements of the super- plasticizer in accordance with the requirements of "ASTM-C-494 types G and F, ASTM C494 [11]".

\subsection{Mix Proportion}

In order to study the effective parameters, several mixing proportions were investigated. These mixing proportions are shown in Table (3).

\subsection{Mixing of Concrete}

Mixing of concrete was batched based on these procedures: Weigh all constituent materials. Then, Place cement and metakaolin only in mixer and mix for 2 minutes (Dry Mix) to break up any clumps. Then, add half of water to premix slowly over the period for 1 minute. After 1 minute, add the remaining water with all Super plasticizer potion to premix over the period for 3 minutes until concrete changes from a dry powder to a thick paste, where the time (For this process, there is a variation according to the cement content). Then, add sand to the mix for 2 minutes. After that add coarse aggregate to the mix for 2 minutes.

\subsection{Curing of Concrete}

The program includes three phases for curing. The first one is standard curing, the second one is steam cured specimens were subjected to a 36 -hour, $80 \%$ humidity, and steam treatment at $65^{\circ} \mathrm{C}$. The steam treatment began with a 2-hour ramp up period to $65^{\circ} \mathrm{C}$ and $100 \%$ humidity followed by a 32-hour hold at the elevated temperature and relative humidity. At the end of this time, the environment was allowed to ramp down to lab conditions over 2 hours by opening the outer lid of the cure chamber. This mean that the net steam treated time is 32 hours only. All specimens were removed after the 36 hour cure process and allowed to return to ambient temperature and water cured until testing occurred. The third type is chemical curing. Liquid curing agents can be sprayed onto the concrete surface with simple tools. It must be applied over the whole surface as early as possible.

\subsection{Measurements}

Compressive strength as hardened concrete property of Metakaolin concrete after 7, 28 and 90 days of age under different types of curing methods and different types of cement were studied. Attention was paid to the chloride penetration test, abrasion resistance and absorption ratio.

\section{RESULTS}

\subsection{Compressive strength}


A total of 144 cubes of $100 \times 100 \times 100 \mathrm{~mm}$ dimensions were examined for compressive strength. Table (4) show the results for the compressive testing. Test was made at ages of 7,28 and 90 days on metakaolin concrete under various types of curing methods and various type of cement. This paper is mainly paying attention to producing high strength concrete and determining the impact of metakaolin volume on several properties of HSC. The compressive strength of 100x100x100 mm cube for each mix was compared according to the metakaolin content, then, to each other, to analyse the effect of the proportions of the concrete components on the development of the mechanical properties of the concrete. Figures 1, 2, 3 and 4 are a graphical representation for the average compressive strength results for each age, and metakaolin content for each mix for different cured specimens. Compressive strength results for mixes contain ordinary Portland cement with replacement 0 and $15 \%$ from metakaolin under standard curing. The compressive strength in mix contain $15 \%$ replacement from metakaolin increased by $13.7 \%, 13.6 \%$ and $13.3 \%$ at ages 7, 28 and 90 day, respectively comparing with the control mix.

Table (1): Materials used

\begin{tabular}{|c|c|c|}
\hline Material & Type & Characterisation \\
\hline \multirow{2}{*}{ Cement } & $\begin{array}{l}\text { Suez } \\
\text { Portland } \\
\text { Cement } \\
52.5 \mathrm{~N}\end{array}$ & $\begin{array}{c}\text { Specific Surface Area = } \\
3590 \mathrm{~cm} 2 / \mathrm{gm} \\
\text { Comply with the } \\
\text { Egyptian standard } \\
\text { specifications }\end{array}$ \\
\hline & $\begin{array}{c}\text { Suez } \\
\text { Sulphate } \\
\text { Resistance } \\
\text { Cement } \\
42.5 \mathrm{~N} \\
\end{array}$ & $\begin{array}{c}\text { Specific Surface Area }= \\
3590 \mathrm{~cm} 2 / \mathrm{gm} \\
\text { Comply with the } \\
\text { Egyptian standard } \\
\text { specifications }\end{array}$ \\
\hline $\begin{array}{c}\text { Fine } \\
\text { Aggregate }\end{array}$ & Sand & $\begin{aligned} \begin{array}{r}\text { Specific Gravity } \\
\text { gm } / \mathrm{cm}^{3}\end{array} & 2.6 \\
\text { Fineness Modulus } & =2.75\end{aligned}$ \\
\hline $\begin{array}{c}\text { Coarse } \\
\text { Aggregate }\end{array}$ & Basalt & $\begin{array}{c}\text { Specific Gravity = } 2.6 \\
\mathrm{gm} / \mathrm{cm}^{3} \\
\text { Water Absorption Ratio } \\
=1.85\end{array}$ \\
\hline $\begin{array}{l}\text { Chemical } \\
\text { Admixture }\end{array}$ & $\begin{array}{c}\text { Super } \\
\text { plasticizer }\end{array}$ & $\begin{array}{c}\text { Increasing the } \\
\text { workability of concrete } \\
\text { without additional } \\
\text { amount of water. Sika } \\
\text { Viscocrete } 3425\end{array}$ \\
\hline Additive & Metakaolin & $\begin{array}{c}\text { Specific Gravity }=2.65 \\
\mathrm{gm} / \mathrm{cm}^{3}\end{array}$ \\
\hline
\end{tabular}

Table (2): Aggregate Grading

\begin{tabular}{|c|c|c|}
\hline $\begin{array}{c}\text { Sieve } \\
\text { Size }\end{array}$ & Basalt & Sand \\
\hline 12.5 & 100 & 100 \\
\hline 9.5 & 99.85 & 100 \\
\hline 4.75 & 51.9 & 95.9 \\
\hline 2.36 & 0.3 & 91.22 \\
\hline 1.18 & 0 & 77.63 \\
\hline 0.6 & 0 & 4.05 \\
\hline 0.3 & 0 & 0.91 \\
\hline 0.15 & 0 & 0.02 \\
\hline
\end{tabular}

Table (3): Mix Proportions for the studied mixes

\begin{tabular}{|c|c|c|c|c|c|c|c|}
\hline No & $\frac{U}{k}$ & 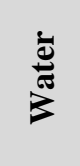 & 己̈ & 总 & 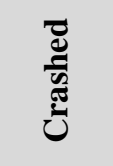 & 窇 & $\stackrel{4}{\Sigma}$ \\
\hline MO 0 & .25 & 112.5 & 450 & 758.09 & 1137.14 & 6.075 & 0 \\
\hline MO 15 & .25 & 112.5 & 382.5 & 758.09 & 1137.14 & 6.075 & 67.5 \\
\hline MS 0 & .25 & 112.5 & 450 & 758.09 & 1137.14 & 6.075 & 0 \\
\hline MS 15 & .25 & 112.5 & 382.5 & 758.09 & 1137.14 & 6.075 & 67.5 \\
\hline
\end{tabular}


Table (4): Compressive Strength Tests Results

\begin{tabular}{|c|c|c|c|c|c|c|c|c|c|}
\hline \multirow{3}{*}{ Mix } & \multicolumn{9}{|c|}{ Compressive Strength } \\
\cline { 2 - 11 } & \multicolumn{3}{|c|}{ Standard Curing } & \multicolumn{3}{c|}{ Steam Curing } & \multicolumn{3}{c|}{ Chemical Curing } \\
\cline { 2 - 10 } & 7 Day & 28Day & 90Day & 7 Day & 28Day & 90Day & 7 Day & 28Day & 90Day \\
\hline MO0 & 705 & 825 & 882.67 & 831.67 & 951.67 & 1068.33 & 608.33 & 726.67 & 763.33 \\
\hline MO15 & 801.67 & 937.67 & 999.67 & 955 & 1036.67 & 1216.67 & 705 & 810 & 895 \\
\hline MS0 & 721.67 & 849.67 & 955.67 & 856.67 & 983.33 & 1113.33 & 636.67 & 768.67 & 806.67 \\
\hline MS15 & 825 & 967.67 & 1015 & 975.67 & 1160 & 1266.67 & 735 & 845 & 950 \\
\hline
\end{tabular}

Table (5): Tests Results

\begin{tabular}{|c|c|c|c|c|c|c|c|}
\hline \multirow{2}{*}{ Mix } & \multicolumn{4}{|c|}{ Abrasion Resistance } & \multicolumn{2}{c|}{ Absorption Ratio } & \multicolumn{2}{c|}{ Chloride Penetration Test } \\
\cline { 2 - 8 } & $\begin{array}{c}\text { Standard } \\
\text { Curing }\end{array}$ & $\begin{array}{c}\text { Steam } \\
\text { Curing }\end{array}$ & $\begin{array}{c}\text { Chemical } \\
\text { Curing }\end{array}$ & $\begin{array}{c}\text { Standard } \\
\text { Curing }\end{array}$ & $\begin{array}{c}\text { Steam } \\
\text { Curing }\end{array}$ & $\begin{array}{c}\text { Charge Passed } \\
\text { (Coulombs) }\end{array}$ & $\begin{array}{c}\text { Chloride Ion } \\
\text { Penetrability }\end{array}$ \\
\hline MO0 & 0.55 & 0.43 & 0.74 & 1.35 & 1.2 & 1100 & Low \\
\hline MO15 & 0.48 & 0.35 & 0.69 & 0.8 & 0.72 & 370 & Very Low \\
\hline MS0 & 0.63 & 0.54 & 0.95 & 1.22 & 1.05 & 1300 & Low \\
\hline MS15 & 0.6 & 0.49 & 0.81 & 0.5 & 0.46 & 550 & Very Low \\
\hline
\end{tabular}

Table (6): Compressive strength results for metakaolin concrete under different degrees of temperatures and different type of cement

\begin{tabular}{|c|c|c|c|c|c|}
\hline \multirow{2}{*}{ Mix } & \multicolumn{5}{|c|}{ Compression test 28 day } \\
\cline { 2 - 6 } & At ${ }^{\circ} \mathbf{C}$ & At $\mathbf{2 0 0}^{\circ} \mathbf{C}$ & At $\mathbf{4 0 0}^{\circ} \mathbf{C}$ & At $^{\circ} 0^{\circ} \mathbf{C}$ & ${\text { At } \mathbf{8 0 0}^{\circ} \mathbf{C}}^{\circ}$ \\
\hline MO0 & 700 & 630 & 480 & 285 & 50 \\
\hline MO15 & 810 & 720 & 565 & 320 & 59 \\
\hline MS0 & 720 & 645 & 495 & 290 & 55 \\
\hline MS15 & 825 & 733 & 585 & 330 & 60 \\
\hline
\end{tabular}

Compressive strength results for mixes encompass sulphate resistance cement with replacement 0 and $15 \%$ from metakaoline under standard curing. The compressive strength in mix includes $15 \%$ replacement from metakaolin increased by $14.3 \%$, $13.9 \%$ and $6.0 \%$ at ages 7,28 and 90 day, respectively comparing with the control mix. Compressive strength results for mixes contain ordinary Portland cement with replacement 0 and $15 \%$ from metakaoline under steam curing. The compressive strength in mix includes 15\% replacement from metakaolin increased by $14.8 \%, 9.0 \%$ and $12.2 \%$ at ages 7,28 and 90 day, respectively comparing with the control mix. Compressive strength results for mixes contain sulphate resistance cement with replacement 0 and $15 \%$ from metakaolin under steam curing. The compressive strength in mix includes $15 \%$ replacement from metakaolin increased by $13.9 \%$, $17.9 \%$ and $13.8 \%$ at ages 7,28 and 90 day, respectively comparing with the control mix. Compressive strength results for mixes include ordinary Portland cement with replacement 0 and $15 \%$ 
from metakaoline under chemical curing. The compressive strength in mix includes $15 \%$ replacement from metakaolin increased by $15.9 \%$, $11.5 \%$ and $17.2 \%$ at ages 7,28 and 90 day, respectively comparing with the control mix Compressive strength results for mixes includes sulphate resistance cement with replacement 0 and $15 \%$ from metakaolin under chemical curing. The compressive strength in mix includes $15 \%$ replacement from metakaolin increased by $15.4 \%$, $9.0 \%$ and $17.8 \%$ at ages 7,28 and 90 day, respectively comparing with the control mix.

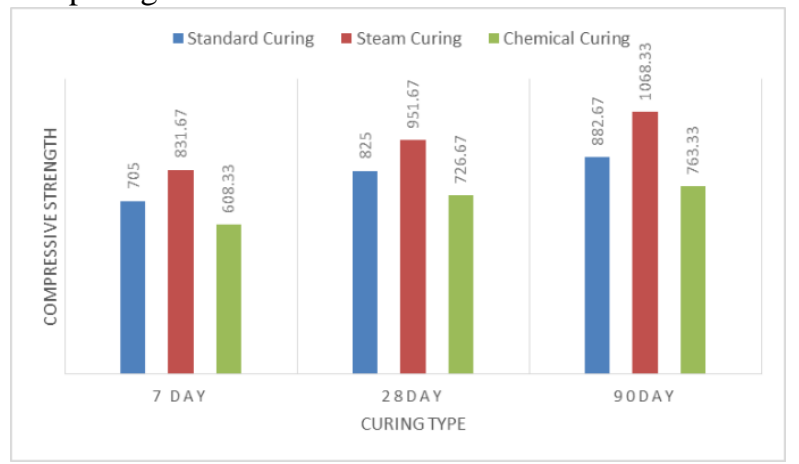

Figure 1: Compressive strength results for mix MO0 under different type of curing

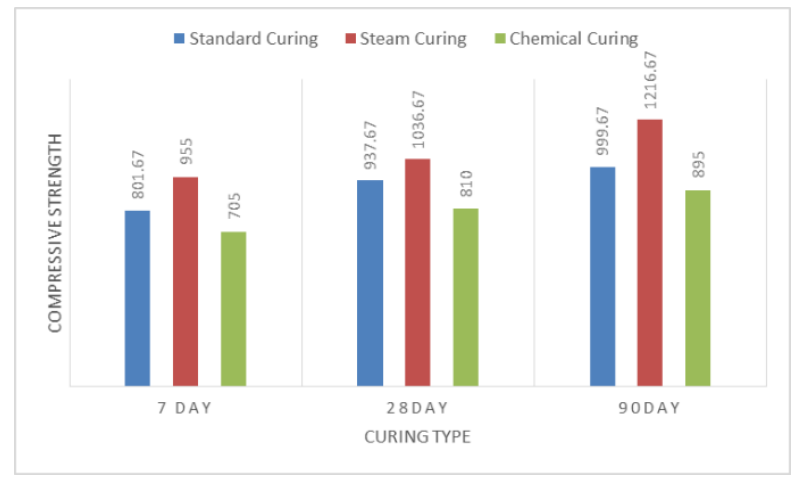

Figure 2: Compressive strength results for mix MO15 underdifferent type of curing

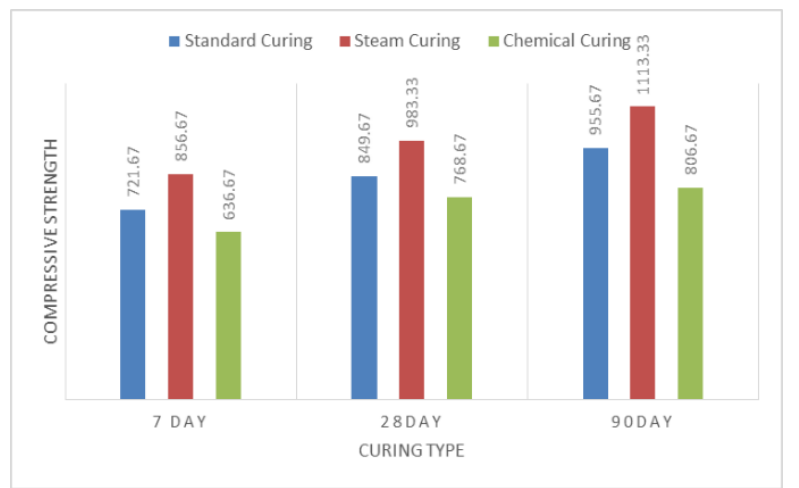

Figure 3: Compressive strength results for mix MS0 under different type of curing

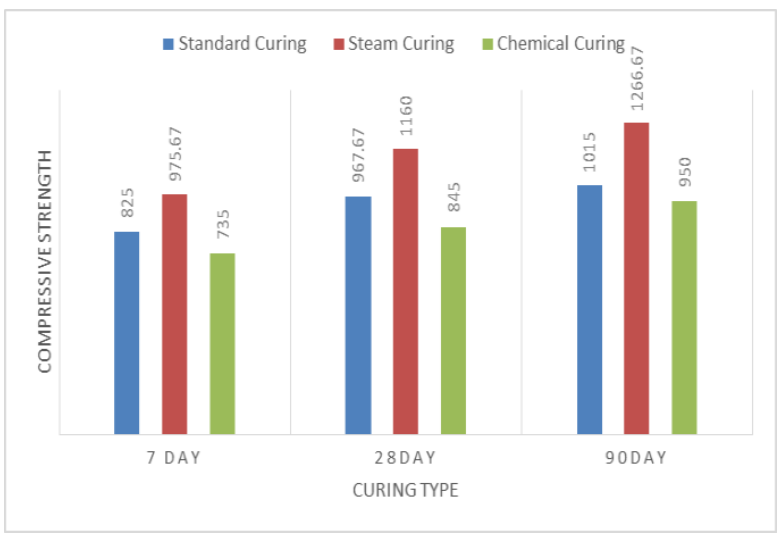

Figure 4: Compressive strength results for mix MS15 under different type of curing

\subsection{Abrasion Resistance}

The abrasion resistance of a 60-cube specimen with 70x70x $70 \mathrm{~mm}$ for all mix was compared solely according to the metakaolin content, and then later to each other to analyse the effect of the proportions of the components of concrete in promoting the absorption ratio for HSC.

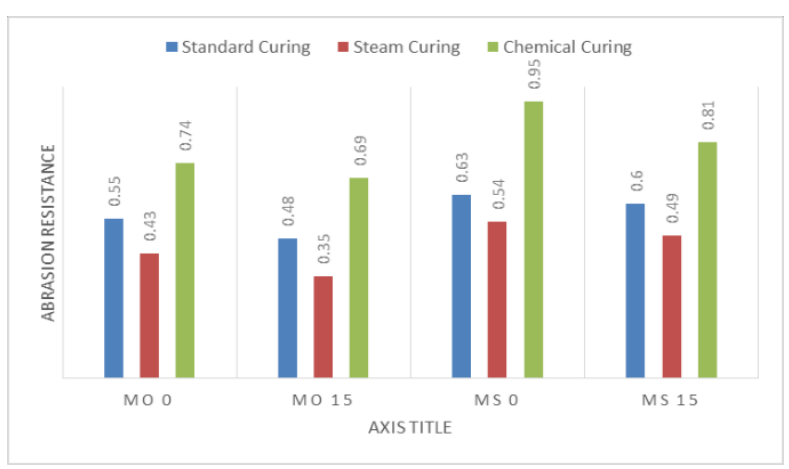

Figure 5: Development comparison between abrasion resistances for Mix contains metakaolin under different type of curing at (28 Days)

Figure 5 is a graph represents the average abrasion resistance results at 28 day for mixes contains different type of cement with $0 \%$ and $15 \%$ from metakaolin as a replacement ratio from cement. From the result at age 28-day, steam curing.

increases the abrasion resistance by $21.8 \%$ and chemical curing decrease the abrasion resistance by $25.7 \%$ at mix MO0. Steam curing increase the abrasion resistance by $27.1 \%$ and chemical curing decrease the abrasion resistance by $30.4 \%$ at mix MO15. Steam curing increase the abrasion resistance 
by $14.3 \%$ and chemical curing decrease the abrasion resistance by $33.7 \%$ at mix MS0. Steam curing increase the abrasion resistance by $18.3 \%$ and chemical curing decrease the abrasion resistance by $25.9 \%$ at mix MS15. Steam curing resort to improve the abrasion resistance compared to other curing method. The results illustrate that abrasion resistance of metakaolin concrete is directly proportional to compressive strength of metakaolin concrete pavement, i.e. when the abrasion resistance increases, the compressive strength of metakaolin concrete pavement increases.

\subsection{Absorption Ratio}

The absorption ratio of a cube specimen with 100x 100x $100 \mathrm{~mm}$ for all mix was compared solely based to the metakaolin content, and then later to each other to test the effect of the proportions of the ingredients of concrete in promoting the absorption ratio for HSC.

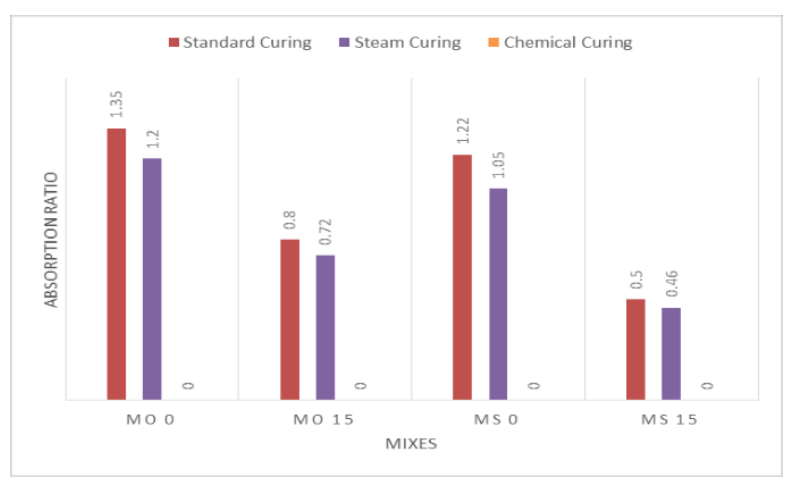

Figure 6: Development comparison between absorption

ratios for Mix contains metakaolin

under different type of curing at (28 Days)

Figure 6 is a bar graph represents the average absorption ratio results at 28 day for mixes comprises various type of cement with $0 \%$ and $15 \%$ from metakaolin as a replacement ratio from cement. The result shows that, Steam curing prone to decrease the absorption ratio compared to other curing method. The reduction in water absorption ratio is due to the beneficial effect of the filling effect of ultrafine metakaolin as well as due to its pozzolanic reaction.

\subsection{Chloride Penetration Test}

The chloride penetration test of a cylinder specimen with a diameter of $10 \mathrm{~cm}$ and with height of $10 \mathrm{~cm}$ for all mix was compared solely based on the metakaolin content, and then later to each other to examine the impact of the proportions of the components of concrete in development the chloride penetration test for HSC.

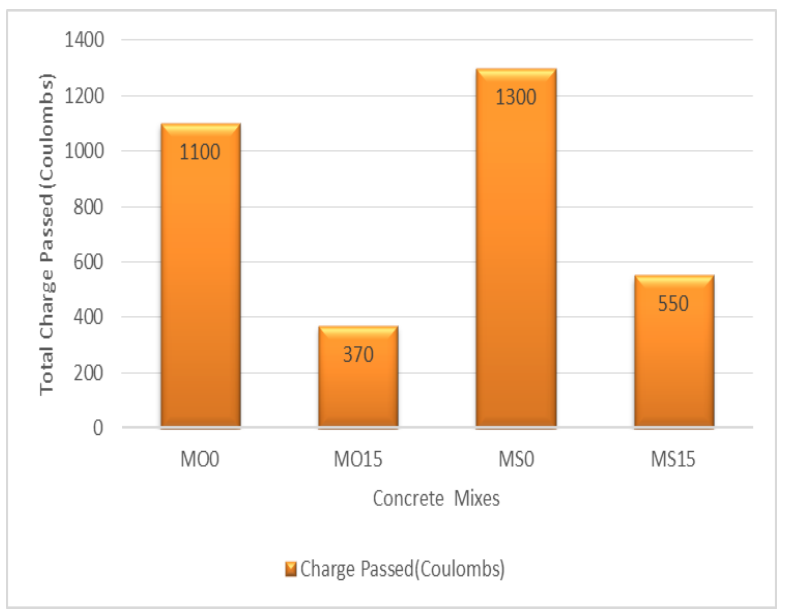

Figure 7: Development the chloride penetration test

results for Mix contains metakaolin

and different types of cement at (28 Days)

Figure 7 is a graph represents the chloride penetration test results at 28 day for mixes comprises various type of cement with $0 \%$ and $15 \%$ from metakaolin as a replacement ratio from cement. The results illustrate that, all the metakaolin concrete mixes show very low chloride permeability. Thus, means that high reactivity metakaolin substantially reduced chloride ion penetration in metakaolin concrete and such declines are suggested to have a significant effect on the service life of reinforced concrete in chloride environments.

\subsection{Impact of heating on compressive strength in metakaolin concrete}

As the aim is to examine the impact of heating duration subjected to residual properties of metakaolin concrete, the specimen will be exposed to temperature below degrees $0^{\circ} \mathrm{C}, 200^{\circ} \mathrm{C}, 400^{\circ} \mathrm{C}, 600^{\circ} \mathrm{C}$ and $800^{\circ} \mathrm{C}$, respectively. Samples are to be heated for 60 minutes. The concrete samples were tested for 28 day. The samples will be heated up using a furnace possessed by Concrete Laboratory. The heated cubes were cooled at room temperature for 24 hours and then subjected to cube compressive strength test. Table (6) shows the results for the compressive testing. Test was made at age of 28 days on metakaolin concrete under various degrees of temperatures and various type of cement. 


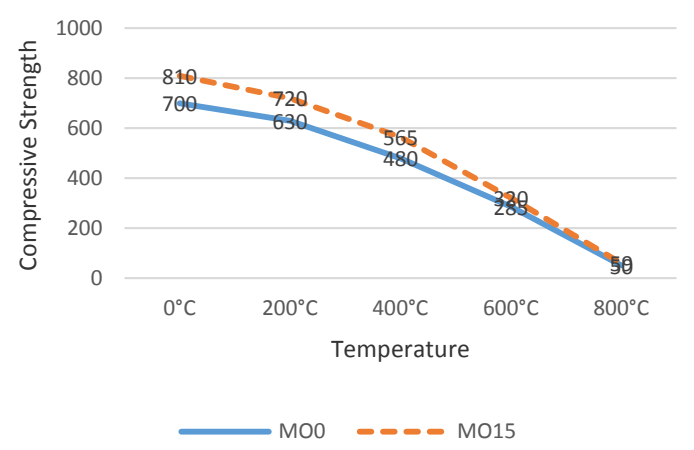

Figure 8: Development compressive strength results for metakaolin concrete under different degrees of temperatures and ordinary Portland cement mixes at (28 Days)

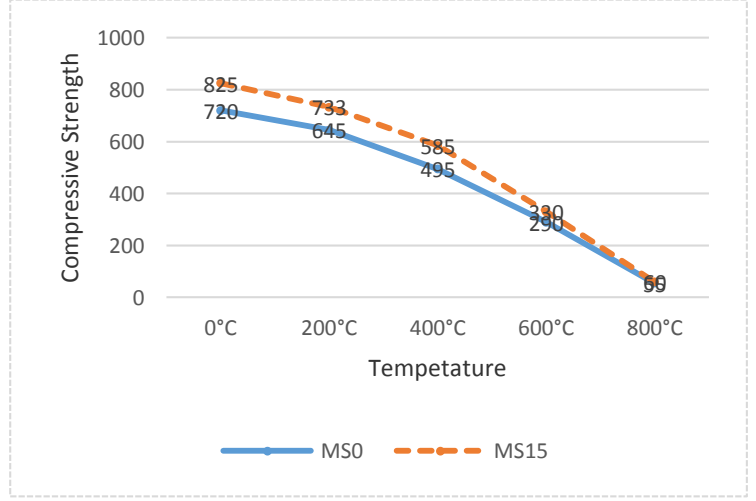

Figure 9: Development compressive strength results for metakaolin concrete under different degrees of temperatures and Sulphate resistance cement mixes at (28 Days)

Figure 8 illustrates the compressive strength results for metakaolin concrete under various degrees of temperatures and ordinary Portland cement mixes. Compressive strength results for mix $\mathrm{MO} 0$ affected by metakaolin materials as replacement of cement by weight under various degrees of temperatures and various type of cement at 28 days. Compressive strength decreases as the temperature increases by $10.0 \%, 31.43 \%, 59.3 \%$ and $92.9 \%$ under temperature degrees $200^{\circ} \mathrm{C}, \quad 400^{\circ} \mathrm{C}, \quad 600^{\circ} \mathrm{C}$ and $800^{\circ} \mathrm{C}$, respectively. Compressive strength results for mix MO15 affected by metakaolin materials as replacement of cement by weight under different degrees of temperatures and various type of cement at 28 days. Compressive strength decreases as the temperature increases by $11.11 \%, 30.25 \%, 60.5 \%$ and $92.7 \%$ under temperature degrees $200^{\circ} \mathrm{C}, 400^{\circ} \mathrm{C}$, $600^{\circ} \mathrm{C}$ and $800^{\circ} \mathrm{C}$, respectively. Figure (9) shows compressive strength results for metakaolin concrete under various degrees of temperatures and Sulphate resistance cement mixes. Compressive strength results for mix MS0 affected by metakaolin materials as substitute of cement by weight under various degrees of temperatures and different type of cement at 28 days. Compressive strength decreases as the temperature increases by $10.42 \%, 31.25 \%, 59.75 \%$ and $93.4 \%$ under temperature degrees $200^{\circ} \mathrm{C}, 400^{\circ} \mathrm{C}$, $600^{\circ} \mathrm{C}$ and $800^{\circ} \mathrm{C}$, respectively. Compressive strength results for mix MS15 affected by metakaolin materials as replacement of cement by weight under various degrees of temperatures and various type of cement at 28 days. Compressive strength decreases as the temperature increases by $11.15 \%, 29.1 \%, 60.0 \%$ and $91.7 \%$ under temperature degrees $200^{\circ} \mathrm{C}, 400^{\circ} \mathrm{C}$, $600^{\circ} \mathrm{C}$ and $800^{\circ} \mathrm{C}$, respectively. From studied result metakaolin concrete have a very positive impact on the compressive strength at the age of 28 days and after exposure to escalated temperature. Visual inspection of the heated samples showed minor cracking up to $500^{\circ} \mathrm{C}$ but pronounced cracking beyond that. At $800^{\circ} \mathrm{C}$, concrete looked in bad shape. Colour changes after heating were examined studied. Normal grey colour of cement was maintained up to $200^{\circ} \mathrm{C}$ and even at $400^{\circ} \mathrm{C}$. But at $400^{\circ} \mathrm{C}$, color turned brown. At $500^{\circ} \mathrm{C}$, the grey shade turned darker but at $600^{\circ} \mathrm{C}$, it turned whit grey. At $800^{\circ} \mathrm{C}$, the color got changed to yellow brown.

\section{CONCLUSIONS}

The following thesis is inferred from this study.

1. Mixes contain ordinary Portland cement and $15 \%$ replacement from metakaolin, compressive strength increased about $9.0 \sim 17.6 \%$ related to the control mix. At mixes contain Sulphate resistant cement and 15\% replacement from metakaolin, compressive strength increased about $6.0 \sim 17.9 \%$ related to the control mix.

2. Abrasion resistance of metakaolin concrete is increased as compressive strength of metakaolin concrete pavement increases.

3. The reduction in water absorption ratio is due to the beneficial effect of the filling effect of ultrafine metakaolin besides its pozzolanic reaction.

4. All the metakaolin concrete mixes demonstrates very low chloride permeability. Thus, means that high reactivity metakaolin substantially reduced chloride ion penetration in metakaolin concrete and such reductions can be forecasted to have a substantial impact on the life span of reinforced concrete in chloride environments.

5. The compressive strength of concrete decrease as the heating duration increases. The lowest compressive strength was recorded at $800^{\circ} \mathrm{C}$ after 
being exposed to a sixty-minute heating. At this stage, the compressive strength of the concrete decreases to about $10 \%$ of the actual value of the concrete and also loses part of its mass as a result of the increase in evaporated water due to the length of the heating period, since the duration of the heating period affects the loss of free water from the concrete and affects the deterioration of the hydration products in concrete.

6. The results show that, metakaolin concrete have a very positive impact on the compressive strength at the age of 28 days and after exposure to elevated temperature.

\section{Credit Authorship Contribution Statement}

S Nour Eldin: Methodology, Resources, Formal analysis, Investigation, Writing original draft, Review \& Editing.

Sh. Ragheb: Data Curating, Writing - Review \& Editing.

H. M. Hassan: Data Curating, Supervision.

K. Sharobim: Validation, Resources, Supervision, Visualization, Project administration.

\section{Declaration of Competing Interest}

The authors declare that they have no known competing financial interests or personal relationships that could have appeared to influence the work reported in this paper.

\section{References}

[1] Effect of Metakaolin on the Properties of Concrete, International Research Journal of Engineering and Technology (IRJET), Volume: 04 Issue: 07 | July 2017.

[2] S. Sujjavanich, P. Suwanvitaya, D. Chaysuwan, G. Heness, Synergistic effect of metakaolin and fly ash on properties of concrete, Constr. Build. Mater. 155(2017) 830-837.

[3] Sha, W., Pereira, B., Differential scanning calorimetric study of ordinary Portland cement paste containing metakaolin and theoretical approach of metakaolin activity, Cement Concrete Comp, 23, 6, 2001, pp. 455-461.

[4] Effect of Calcination Temperature of Kaolinite Clay on the Properties of Portland Cement Pastes Containing Metakaolin, Al-Azhar Bull. Sci. Vol. 19, No. 1 (June.): pp. 101-121, 2008.

[5] International Congress: Challenges of Concrete Construction, Dundee, Scotland, September 2002. In Innovations and Developments in Concrete Materials and Construction, Edited by R.K. Dhir, P.C. Hewlett, and L.J. "The Effect of Metakaolin On Concrete Properties" Cetenyi, pp. 81-89, Dundee, 2002.

[6] Effect of Pozzolanic Additives on the Strength Development of High Performance Concrete, Laura Dembovskaa , Diana Bajarea, ${ }^{*}$, Ina Pundieneb , Laura Vitolaa a Riga Technical University, Department of Building Materials and Products, Institute of Materials and Structures, Riga, Latvia b Vilnius Gediminas Technical University, Sauletekio str.11, 10223, Vilnius, Lithuania, ScienceDirect , Procedia Engineering 172 ( 2017 ) $202-210$.

[7] IOSR Journal of Mechanical and Civil Engineering (IOSR-JMCE) ISSN: 2278-1684,'” MetakaolinPozzolanic Material for Cement in High Strength Concrete" PP: 46-49, 2012.

[8] E.S.S. 4756-1/2009: Ordinary Portland cement, Egyptian Standard Specification, Egypt, 2006.

[9] ES 4756-1 (2013): Cement Part :( 1) Composition, Specifications and Conformity Criteria for Common Cements, Egypt, 2013.

[10] EN 197-1:2011: European Standard defines and gives the specifications and conformity criteria for common cements.

[11] ASTM-C-494: American Standard Specification for Chemical Admixtures for Concrete, 2003 